\title{
Student Fearlessly Attacking Teacher and Others: A Qualitative Study of Ethics on High School and Colleges Students in Bekasi City
}

\author{
Adhy Firdaus \\ Graduate Programs of STIE, Economics School of Higher Educations, Jakarta, Indonesia \\ Email: adhyfirdaus@gmail.com
}

How to cite this paper: Firdaus, A. (2019) Student Fearlessly Attacking Teacher and Others: A Qualitative Study of Ethics on High School and Colleges Students in Bekasi City. Open Journal of Social Sciences, 7, 113-125.

https://doi.org/10.4236/jss.2019.711009

Received: October 15, 2019

Accepted: November 17, 2019

Published: November 20, 2019

Copyright $\odot 2019$ by author(s) and Scientific Research Publishing Inc. This work is licensed under the Creative Commons Attribution International License (CC BY 4.0).

http://creativecommons.org/licenses/by/4.0/

\begin{abstract}
Indonesian are polite and kind to others, and nowadays, central and local government of the Republic of Indonesia (both provincial and district) are actively implementing programs of 9-year compulsory education. However, at the same time, the acts of ethical infractions were very widespread and were done by students. Group fighting between students and other negative activities that were done by a student in a group or alone often occur and are very worrying. The other event of violating ethics were: high school student attacking substitute teacher, student bullying teacher, attacking school cleaning service personnel, and much more. The purpose of this paper is to uncover deeply what are the reasons or the backgrounds of the unethical behavior of student's violence against teachers and other personnel in school and communities. The setting of this research is in Bekasi City, West Java Province of Indonesia. This research used a qualitative approach with grounded research design with questioners, field observations and interviews data gathering. The research is focused on ethical behavior and knowledge of high school and undergraduate university students in the setting area. The research questions were: 1) Why student or students do violence to teacher and others?. 2) What is underlying their violent behaviors? The research result indicated that the level of educations has strong influences on the ethical behaviors of a person. And research also found that there were four factors that strongly influenced the act of unethical behavior of students. This research suggested a model of ethical teaching in educational institutions.
\end{abstract}

\section{Keywords}

Education, Ethics, Institutions, Violence, Interview 


\section{Introduction}

The vision of national education of Indonesia is the conscientiousness of the education system as a social institution that is strong and authoritative to empower all citizens of Indonesia and to develop a quality human who is capable and proactive in answering the challenges of Era which always changed.

One of the principles of education is that education is organized as a process of culturalization and empowerment of learners that lasted a lifetime. In that process, educators are required to provide a model, build willpower and develop the potential and creativity of learners. The implication of this principle is a paradigm shift in the educational process, namely from the paradigm of teaching into a paradigm of learning. Learning is a process of interaction of learners with teachers and learning resources in a learning environment [1]. In a morally corrupt world, education remains the sole rescue anchor to guide new generation towards rehabilitation of moral value [2].

The educational system in Indonesia is divided into two ways namely formal education and informal education [3]. Levels of the formal educations namely: Basic levels are Kindergarten-TK, Elementry School-SD or Madrasah Ibtida'iyyah-MI, Junior High School-SMP or Madrasah Tsanawiyah-MTs, and High School-SMA, Madrasah Aliyah-MA, or Vocational High School-SMK; High level educations, University and College. Name for learners of basic level educations is "Pelajar/pupil" and name for learners of high-level educations is "Mahasiswa/Student". Aside from above, the pupil of high school is called a student also.

Implication of the Indonesian educational system is that every learner hopefully become better human form before, including better in morality and ethics in day-to-day lives. It should be assumed that the education system also inculcated and/or taught ethics to students.

Phenomena that occur nowadays in Indonesia, where its people were polite and kind to others, is that while central and local government-both provincial and district-are actively implementing program of 9-year compulsory education. However, at the same time the acts of ethical infractions were very widespread and were done by student. Group fighting and other negative things that were done by a student in a group or alone often occur and are very worrying. The other event of violating ethics were: high school student attacking substitute teacher [4]; attacking school cleaning service personnel [5], student bullying teacher [6] and many other events that violate ethics that were performed by the students. These events were frightening and horrifying and considered to be unethical violence behavior because students are the hope of the nation for a better future. Dewey (1910) argued that students should prepare for daily professional life through appropriate education combining knowledge and skilled "activity-related" knowledge. He claimed that knowledge, skills, and competences are all linked [7].

Some prior research of ethics found females to be more ethical than male (Betz et al, 1989) in [8]. The result survey also suggests that age is a determining 
factor in making an ethical decision [8]. Much research is conducted on the behavior of students and their perception of ethics. However, no qualitative study has been conducted to uncover deeply what is the reason or reasons or the backgrounds of the unethical behavior of students' violence against teachers and other personnel in school and communities. We conducted this study to do it.

\section{Focus}

The research focuses are:

1) Why student does violence to teacher and others?

2) What underlying their violent behaviors?

\section{Education}

Education is a discipline that is concerned with methods of teaching and learning in school or school-like environments [9]. Education is the process of facilitating learning, or the acquisition of knowledge, skills, values, beliefs, and habits [10]. According to Google Dictionary, education is the process of receiving or giving systematic instruction, especially at school or university [11].

Education in general intended to cultivate the existence of learners that civilize, culturable in the life of locally, nationally, and globally (Tilaar, 2000, in Muhanto, 2005). Furthermore in section 26 Government regulation of the Republic of Indonesia Number 20 year 2003 [3] on national education standard stated that: standard competency of educational level graduate intended to aims to lay or to improve the basic intelligence, knowledge, personality, noble character, and skills for independent living and continue to the next level of education. Meanwhile, college competencies purposed for preparing learners to became a society member who has noble character, knowledge, skills, independence, and attitude to search, finding, developing, also implementing sciences, technologies, and arts that useful for humanity. It is clear that the objective of formal education in Indonesia one of which is having noble character, which means knowing and implementing ethics in their daily lives.

\section{Ethics}

The word "ethics" is derived from the Greek "ethos" meaning "custom" or "habits" [12]. Google Dictionary [11] defines ethics (a) as a moral principle that governs a person's behavior or the conducting of an activity, (b) the branch of knowledge that deals with moral principle. Beekun defined ethics as a set of moral principles that distinguished what is right from what is wrong [13]. Moral or ethical therefore to be defined as human behavior that does not harm other people (living beings) objectively, and that their welfare is not diminished [14].

For Muslim society, they believe that Al-Qur'an, Sunnah and Hadith (sayings) of Prophet Muhammad S.A.W., and Syaria'ah (IslamicLaws) gives them all answers of ethical questions or problems and guidance for behaviour that suitable with ethics (Rise, 2006; \& Abbasi et al., 1989, in [15]). Ethics has an important 
role in education as it has to be related to student's behavior, performance, success, and continuity as a noble person in the long term. Ethics govern a student's behavior as a member of a bigger community. Education can either hold back or promote a good atmosphere, providing better surroundings necessary for the ethical development of students. The ethical culture of an education can be implemented to students by the educational systems. The study revealed that students have a high level of ethics, but it differs when a situation is beyond their control and involve their friends [16].

This study participates in the discussion of the ethical culture of education by deepening the knowledge and understanding the meaning of educational ethical virtues in educational ethical behavior, in other words, we discuss how an education ethical culture and educational ethical virtues are useful for student's ethical development.

\section{Research Methodology}

According to [17] when using a quantitative approach, we some times don't find the "true answer" to the question about what will someone "do". The pattern of human Behavior is only an indication of what is hiding inside the head of the subject [18].

In this research we use a qualitative approach to investigate the topic, using open-ended, in-depth interview which conducted individually with each interviewee. In these interviews, the interviewees could share in detail their perceptions, ideas, and experiences concerning student's ethical behavior and various good and bad practices promoting or hindering ethics among students. The use of qualitative-verificative design and grounded research allowing the researcher to still open against theory, and enable the researcher to jump "free fall" into the field to collect data needed during research. Thus the triangulation process will be smooth and many variations [19]. The most compelling reason in the utilization of grounded theory in the study was to generate valid information through data analysis as the basis of innovation of transition program [20].

A Phenomenological analysis based on discussion and reflections of direct sense perceptions and experiences of the researched phenomenon. A starting point of the strategy is researcher ability to approach a project without a priori assumptions, definitions, or theoretical frameworks [21].

\section{Researcher}

The present of the researcher in qualitative research is important. In qualitative research, the researcher is the main instrument of research (Bungin, 2007; Cresswell, 2003); (Newman and Benz, 1998) in [22].

The researcher leaves in Bekasi City for more than 40 years, he runs a formal educational institution. He once worked as a Chairman of the Board of Education of Bekasi City. The researcher knows the research and how research must be done. Credibility and integrity are a major concern in qualitative research. Trustworthiness in these research use criteria of credibility, dependability, trans- 
formability, and conformability.

\section{Informants}

The informant candidates who suitable and meet the requirement for this research were selected with proportional sampling (Maxwell, 2005) in [23], sampling criteria demanded informants to be chosen based on their experiences to the studied phenomena [19], even if they have only small part. The informants in this research are 12th grade High school Student, undergraduate students and teachers in the City of Bekasi, West Java Province, Indonesia. The following criteria were used in the selection of informants: Students must have at least 11 years of formal educations in the Bekasi area as a pupil or learner (they should be at least in 12th grade on the time of interview or a college student if they had 14 years of formal education). The informant teacher should have at least 5 years of experience of teaching at a formal school in Bekasi.

The Demography data of the selected informants are as follows (Table 1).

The Researcher also plunged directly into the field to observe the incident as well as the behavior of high school and college students at Bekasi City in everyday life. This includes on school time and out of school time. Information and data that was collected then analyzed, verified and processed. The reason why this research focused on the high school and undergraduate college students is because the act of group fighting, attacking teachers and other violence such as bullying others were done by their group of age. In the age of high school and undergraduate students, one's characters are formed, changed and developed. In their age, they searching for character identity, and at this age, we could put the fundamental good norms and ethics to make the young generation become a Nobel person in the future.

\section{Data Collection and Analysis}

After doing field observations, visiting places where students hang-out on campus or out campus, researcher chose 3 (three) informants from high school student, 2 (two) informants from university and/or college students, and 2 (two) informants from high school teachers. In qualitative research, there are no criteria concerning numbers of informants, the most important is they are enough to

Table 1. Demography of informants.

\begin{tabular}{cccccc}
\hline No. & Informant & Level Education & Grade & Age (Years) & Gender \\
\hline 1 & P-1 & HS/SMK & 12 th & 18 & Male \\
2 & P-2 & HS/MA & 12 th & 18 & Male \\
3 & P-3 & HS/SMA & 12 th & 17 & Female \\
4 & S-1 & College & Jun/Sm-5 & 22 & Male \\
5 & S-2 & College & Soph/Sm-3 & 21 & Female \\
6 & T-1 & University & S-2 & 35 & Female \\
7 & T-2 & University & S-2 & 45 & Male \\
\hline
\end{tabular}


give information and data needed for the said research [22].

An in-depth, face to face, a semi-structured interview was conducted and recorded with each participant as noted by [24]. The participants were explained about the purpose of the research and they give written statements allowing the researcher to use the interview for said research. And they also informed that they are independent in this research, meaning that they can refuse to participate or terminate anytime they will.

Each interview lasted around 30 minutes to One hour due to the difficulties keeping student informants to stay longer. The recorded interview was transcribed later. Interview was conducted in the place where informants usually hang-out, the place where they feel comfortable and save from disturbances. The semi-structured interview consisted of general open-ended questions that were followed by targeted questions about the ethics and behavior to get in-depth and detailed pieces of information on the interviewee's perceptions and experiences of phenomena. The interview was done three times: First to get general information about the phenomena, second for Interviewees' perceptions and experiences, and third to get things that left behind or to fill the gap. Researchers taking notes during interviews, noted the body language and gestures of interviewees to get deep feelings of what they said. In order to assert the confirmability of research, peer debriefing was done with colleagues.

The recorded interview was transcribed with the help of other parties, this person is different from the colleagues in peer debriefing. This is to maintain the dependability and truth value of research [22].

The method of Qualitative content analysis was used because it provides a systematic procedure for coding and classifying themes from the text content [25]. Interview transcripts were carefully read several times, highlighting quotations (sentences and longer parts of texts) that represented ethical virtues, and next coded the data according to predetermined categories, after that, how well the quotations are fitted in the coding categories were reviewed and modified if necessary.

The researcher revisits the field several times after the interview to collect some more pieces of information and to get a deeper feeling about the life of a student which in line with the research topic.

Data collection was done through a research instrument of deep structured and unstructured interviews in phases [18]. Data were taken also from the researcher's notes, deep interview notes, notes of events around informants and in setting, and information from surrounding informants, records, etc. [26].

\section{Findings}

The interviews and field study uncovers Four factors that influenced student to assault teacher and/or school personnel, these factors are 1) No ethics subject in school, 2) Friend's influences, 3) Family or Home's tensions, 4) Student's inner factors. 


\section{No Ethics Subject in School}

The researcher found the fact that there was no ethics subject in the students' school list of lessons, there was a subject of Islamic religious education there and the subject of Pancasila and Citizenship. There were no ethics or ethical behavior subject et all. No subject specifically on ethics in school subjects programs. The good behavior was thought in the Islam Religious subject, thy called "Pendidikan Agama Islam/PAI" or Islamic Religion education. This subject lesson was a minority subject, only 1 (one) credit hour. This means trough school programs which last for Three years they only teach for 1 (one) class hour in every (six month semester). With these conditions at school, ethics should be taught intensively at home. The following remarks indicate this:

Ethics lesson? No sir, none. No ethics subject. We were just taught a religion that teaches us good and bad. It's also just for little time. Once a week for one study hour that is 45 minutes (P-1).

Specifically, there were no subjects ethics at school, the student gets a lesson about good and bad from the teacher. Not from a specific subject. So, if you learn ethics... how his teacher "Ajah" (depend on the teacher) (T2).

If the teacher "care" on the behavior or culture of his students, then he gave them guidance, that just passing then... for the most, if student conducted serious or fatal mistakes, then they gave them long and much advice and guide (T-1).

Good behavior lesson was taken from religious education, but religious subject's teacher. Only those teachers taught us which good and which bad, that lesson were according to religiosity (P-2).

There were lessons concerning Pancasila's Moral Educations which taught a student how to behave and to life which appropriate and in way of Pancasila (Indonesian National ideology which is based on local wisdom). Nowadays... it must be somewhere out there... don't know laaah... (T-2).

\section{Friends Influences}

The interviewees indicated that one of the reasons that encourage students to perform the act of bullying to teachers is the influence of friends. Friend will stay away from him if he did not dare to do it, he will be excommunicated. The following statements reflect this:

Usually, our friends pushed to do it... to be togetherness (P-3).

When we are together in the "gang"... well... can't reject ...we did it together and it was fun, not good but fun... we regretted after that... I was sad... very very sad... (P-2).

It was worrying when a group of students gets together because everyone can influence others to do violence. And they did not want to be excommunicated or left behind and threw out from their community (T-2).

The respondents were showing concern and regret. The student informant 
realized the wrongdoing and they knew that it was unethical. Increasing age makes them more mature and more ethics this in line with [8].

A relatively broad, deep and right on target of ethics education needs to be intensified among students. The interviewee also indicates that in addition to friends at school they also warn about friends from out of school especially unemployed alumni who prowl around the school area. This person usually insisted on their bad influence on the students without the knowledge of teachers and/or the school principal. This is illustrated in the following example:

And... there was a person or two who play around school, they used to be a student in the school but they already out, don't know whether they graduated or dropped out. They sometimes took to the things that are not good or outside boundaries (S-1).

The interviewees reported that when they have a lot of activities in school they did not have time to go around bullying someone. They do not have time to even think about it. The concentrations and focus only on school.

Finally, the interviewees described that in good school systems, where having the best ethical behavior is crucial to the students for their future professional life for the good shake of nation.

\section{Family's Tensions}

The interviewees indicated a little bit hesitated when revealed the family's pressure on students (including them).

With regard to the family, the interviewees indicated that family was an important and very valuable element of the ethical development of students. For example in the time when student having trouble or problem that he or she can not solve, then the first people they went to must be their family, father and/or mother to be exact. In the time when things went bad, it was indispensable that the father's figure gave them support, and also assistance to passed a difficult time. In addition, the interviewees indicated that such encouragement and trust from the parent are essential in student's ethical behavior so that giving students soft attention they need would provide the opportunity for them to be ethics, noble, and caring. However, sometimes things did not go the way we expected. The realities of the student conducting violence behavior were opposite to what we wish to happen.

The interviewees also indicated that one of the causes of the unethical behavior of students was the bad tension of family. Authoritarian parents, especially fathers, will drive their teenage children stressed, and frustrating. And finally, the children seek for released. Good things if they found a positive place to release their stress and frustrations like a religious community or study group, how about if they do bad things like bullying teachers or violate others, or doing criminals. The following comments depict this well:

The father was fierce, if he had said a thing you do not allow to disobey, I was tired, I was sick. My home feels like ARMI Barrack (P-1). 
I can not refuse him, when I did it, the home will be like hell. Father is authoritarian. You don't have time to disagree with him at all (P-2).

Another thing that revealed from interviewees was that the family tensions will make student do not like to stay at their home. Then they found unethical activities out of the home.

Interviewees also revealed that "cocky father" also make students feel unhappy and not comfortable at school, to cover their embarrassment, they tend to do something evil in order to make their parent realized of the cocky behavior that embarrasses him or her. The following sentence describes this:

One day there was a teacher that made mistake, one of the student's parent came to school and scold the teacher in front of students.

His father was cocky... so He imitates his father... like father like son.

Father is the central figure in the family. Everything he did and how he did it will be imitated and followed by children. A father figure should be wise, nice, patience, fair, reliable, encouraging, honest, trustworthy, tough, protect, support, and dependable for the children or at least for his. This quality of father is necessary for children to follow and for him to be a leader in the family.

On the contrary, when there was no father in the house, the children will have no clue about what to do and how to do things. They will be a loss... no guidance. In the end, they would act and do things following their emotions and/or anger. Interviewees explained as follows:

A son will take an example from his father. When the father is not home or is not there for him to ask or can not be asked, then the child will be loss, they have no direction to follow (T-1).

Interviewees also indicate that empty house bringing unethical student, this because father and mother work all day, and no time to give their children attention. Children get a role model figure from "the street". No father figure who protects and led, no mother figure who full of love and passion. No parent who shows them the right way to life. Following sentences indicated it:

... his house was empty, his mother and father are working (T-1).

... usually at house no one was feared by him, his father was working in

Bandung... (another city) (T-2).

\section{Students Inner Factors}

Finally, interviewees indicate student inner factor that influenced their violation of ethical behavior. Their willingness to get attention from parents, from teachers, and from the community make them did what they did. Another inner factor that indicated by interviewees is self-esteem, the student wanted to be known, to be recognized as a tough-guy.

Usually, they search another way in order to get attention from parents or from a teacher ( $\mathrm{T}-1)$. 
At school, the teacher could not give full attention to them, therefore parents should give the attention they need in full (T-1).

The tension and lack of attention caused unhappiness that stacked time to time until finally blown up become rebellions (T-2).

The teacher is a parent's image that they found at school, so their dissatisfactions were spilled on teachers or whoever Oldman in school.

Those authoritarian parents, "empty house", and the cocky father in house tensions also aroused rebellion characters in the said students, this rebellious behavior from disappointing house's tension affecting ethical behavior and were brought to the school. The result is the act of violating ethics and law.

Table 2 illustrates how the findings drawn from the significant statements.

Table 2. Data analysis of significance statements, themes, core themes [26].

\begin{tabular}{|c|c|c|c|}
\hline No. & Significance statement & Themes & Core \\
\hline 1 & $\begin{array}{l}\text { Ethics lesson? No sir, none. No ethics subject. We were just taught a religion that } \\
\text { teaches us good and bad. It's also just for little time. Once a week for one study hour } \\
\text { that is } 45 \text { minutes (P-1). } \\
\text { - Specifically, there were no subjects ethics at school, the student gets a lesson about } \\
\text { good and bad from the teacher. Not from a specific subject. So, if you learn } \\
\text { ethics... how his teacher "Ajah" (depend on the teacher) (T2). } \\
\text { - If the teacher's care' on the behavior or culture of his students, then he gave them } \\
\text { guidance, that just passing then... for the most, if student conducted serious or } \\
\text { fatal mistakes, then they gave them long and many pieces of advice and guide (T-1). } \\
\text { - Good behavior lesson was taken from religious education, but religious subject's } \\
\text { teacher. Only those teachers taught us which good and which bad, that lessons were } \\
\text { according to religiosity (P-2). } \\
\text { - There were lessons concerning Pancasila's Moral Educations which taught the } \\
\text { student how to behave and to life which appropriate and in way of Pancasila } \\
\text { (Indonesian National ideology which is based on local wisdom). Nowadays... it } \\
\text { must be somewhere out there... don't know laaah... (T-2). }\end{array}$ & $\begin{array}{l}\text { Ethical lesson was } \\
\text { taught rarely by advice } \\
\text { and spiritual guidance }\end{array}$ & $\begin{array}{l}\text { No formal } \\
\text { ethics } \\
\text { education }\end{array}$ \\
\hline 2 & $\begin{array}{l}\text { - Usually, the friend pushed us to be unified. } \\
\text { - When we got together, then... can be avoided. } \\
\text { - It is fun together... they did not dare to challenges... } \\
\text { - Senior or alumni were persuading. They still prowling around campus. }\end{array}$ & $\begin{array}{l}\text { Pushed by Friens } \\
\text { Group solidarity } \\
\text { Senior and/or bad } \\
\text { alumni influences }\end{array}$ & $\begin{array}{l}\text { Friend's } \\
\text { influence }\end{array}$ \\
\hline 3 & $\begin{array}{l}\text { - The father was fierce, if he had said a thing you do not allowed to disobey, I was } \\
\text { tired, I was sick. My home feels like ARMI Barrack (P-1). } \\
\text { - I can not refuse him, when I did it, the home will be like hell. Father is authoritarian. } \\
\text { You don't have time to disagree with him at all. } \\
\text { - One day there was a teacher that made mistake, one of the student's parent came to } \\
\text { school and scold the teacher in front of the student. } \\
\text { - His father was cocky... so He imitates his father... like father like son. } \\
\text { - A son will take an example from his father. When the father is not home or is not } \\
\text { there for him to ask or can not be asked, then the child will be loss, they have } \\
\text { o direction to follow (T-1). }\end{array}$ & Authoritarian parent & Family tensions \\
\hline 4 & $\begin{array}{l}\text { - Usually, they search another way in order to get attention from parents or from the } \\
\text { teacher (T-1). } \\
\text { - At school, the teacher could not give full attention to them, therefore parents should } \\
\text { give the attention they need in full (T-1). } \\
\text { - The tension and lack of attention caused unhappiness that stacked time to time until } \\
\text { finally blown up become rebellions (T-2). }\end{array}$ & $\begin{array}{l}\text { Try to get attention } \\
\text { Self-esteem } \\
\text { Protested/rebellion } \\
\text { character }\end{array}$ & Inner factor \\
\hline
\end{tabular}




\section{Summary of Research Results}

Although interest in ethical education and ethical behavior of students has stirred recently, little research has addressed the meaning of the ethical culture of high school and/or universities for the ethical behavior of students.

First, the finding of this study shows that educational institutions such as high school and colleges or universities formally do not support much on ethical educations to the students. Second, this study examined the element of factors founded that allowing students to conducted unethical behaviors that are important to the educational authorities, teachers, or parents in making programs to reduce unethical behavior of a student, especially the violence one. Adequate pieces of information on the cause of unethical behavior of students such as authoritarian parents, cocky father, empty house were found to be an essential element of family tensions which then adding the tendency to do things that violate ethics. In regard to the friend's influences, friends compulsion, senior or alumni's bad influences, gang pride, and solidarity were found to be those elements that support violence unethical behavior. In regard to inner factors, the eagerness to get parental attention from parents and/or teachers, self-esteem, and rebellion characteristics were found also to be crucial elements of the stimulus of unethical violence behavior.

The study noted that student violence to the teachers and others is to show to their friends that they are a "tough guy" along with the desire to be known and famous among their friends, these criteria are grouped in research findings as "self-esteem". The research finding also indicated that the underlying violence behavior of students is the bad influence of friends or alumni, the empty home and the rebellion characters.

\section{Research Limitations and Further Research}

This study has some limitations. First, the study was conducted in a small setting area of only Bekasi city. We suggest that the larger setting would merit more research in educational ethics and ethical education on students. Additionally, cross-cultural research comparisons would be interesting. Since the informants interviewed were students and teachers, this qualitative interview study could capture only a limited perspective on the topic. Therefore, we suggest that further research might be a fruitful alternative to obtain more knowledge and a deeper understanding of the topic when included more participants from other groups of societies.

Finally, this study focused mainly on the negative aspect of student's ethics and behavior, however, the study also showed that there might be a positive aspect of student's ethical behavior, we suggest that it would be worth studying possible positive contradictions of this study in the future. We agree with the study research that says: it is important for universities to prepare students with ethical knowledge, skills, and values in order to react with ethical dilemmas and capable to make ethical decision once enter in real-world of work [16]. 
This study also intended to provide some pieces of information for future research of students' behaviorand scholars to produce programs that make the next generation better in ethics, knowledge, skills, and lives.

\section{Conclusions}

In conclusion, the aims of this research were to uncover the ethical education on students of high school and/or college or universities and to uncover deeply what is the reason or reasons or the backgrounds of the unethical behavior of students violence against teachers and other personnel in school and communities. This study fosters the idea that the ethical behavior of the student is promoted by education, and educational institutions should be the leading sector of these ethical educations to prepare a student for their future professional life and to save them from doing something bad that they would regret all their lives.

Based on the research findings, we suggest the government, educational institution or school authorities develop a model of ethical teaching in educational institutions which prioritized:

1) The relationship between parents and school to have more often and familiar communication concerning student's ethical characters.

2) Developing the subject of ethics that involves practical activities.

3) Creating a homy environment at school so the student whose parents are out to work does not feel empty at home anymore.

This is to fulfill the students' thirst for parental or family supports, good and familiar friends, and ethical environments.

\section{Conflicts of Interest}

The author declares no conflicts of interest regarding the publication of this paper.

\section{References}

[1] Government of Indonesia (2008) Lampiran PerMenDikNas No. 1 Tahun 2008. Indonesia Minister of Education.

[2] Iorga, M., Ciudoharu, T. and Romedea, S.-N. (2013) Ethics and Unethic. Students and the Unethical Behavior during Academic Years. Procedia Social and Behavioral Science, 93, 54-58. https://doi.org/10.1016/j.sbspro.2013.09.151

[3] Government of Indonesia (2010) Peraturan Pemerintah-(Government Regulation) No. 17 Tahun 2010.

[4] Youtube (2019) Skyline Student Attacking Substitute Teacher.

[5] DetikNews (2019) Murid Tantang Guru/Student Challenged Teacher to Fight. Detik.com, Jakarta.

[6] Ayobandung (2019) Viral Student Bullying Teacher/Viralnya Kasus Bullying Siswa Terhadap Guru. AyoBandung.Com, Bandung.

[7] De Graaf, F.J. (2009) Ethics and the Behavioural Theory: How Do Professional Asses Their Mental Models? Journal of Business Ethics, 157, 933-947.

https://doi.org/10.1007/s10551-018-3955-6 
[8] Rueger, D. and King, E.W. (1992) A Study of the Effect of Age and Gender upon Student Business Ethics. Journal of Business Ethics, 11, 179-186. https://doi.org/10.1007/BF00871965

[9] Naka, A. (2019) Education Definition.

[10] Wikipedia (2019) Education Wikipedia.

[11] Google (2019) Dictionary.

[12] Branch (2019) The Basic of Philosophy.

[13] Beekun, R.I. (1996) Islamic Business Ethics. International Institute of Islamic Business Thought Copyright, Herndon. https://doi.org/10.2307/j.ctvk8w1zv

[14] Conrad, C.A. (2018) Business Ethics: A Philosophical and Behavioral Approach. Springer International Publishing AG, Part of Springer Nature, Berlin.

[15] Tsalikis, J. and Lassar, W. (2009) Measuring Consumer Perception of Business Ethical Behaviour in Two Muslim Countries. Journal of Business Ethics, 89, 91-98.

[16] Rodzalan, S.A. and Saat, M.M. (2016) Ethics of Undergraduate Students: A Study in Malaysian Public Universities. International Journal of Information and Education Technology, 6, 672-678. https://doi.org/10.7763/IJIET.2016.V6.772

[17] Brand, V. (2008) Empirical Business Ethics Research: An Paradigm Analysis. Journal of Business Ethics, 86, 429-449. https://doi.org/10.1007/s10551-008-9856-3

[18] Bungin, B. (2007) Penelitian Kualitatif: Komunikassi, Ekonomi, Kebijakan Publik, dan Ilmu Sosial Lainnya. Kencana, Jakarta, Vol. 2.

[19] Creswell, J.W. (2007) Qualitative Inquiry and Research Design: Choosing among Five Traditions. Second Editions, Sage Publications, Inc., Thousand Oaks.

[20] Ebona-Abamonga (2019) Grounded Theory Approach: Its Steps and Procedures in Scientific Studies. IOER International Multidisciplinary Research Journal, 1, 95-105.

[21] Pathak, V.C. (2017) Phenomenological Research: A Study of Lived Experiences. International Journal of Advance Research and Innovative Ideas in Education, 3, $1719-1722$.

[22] Firdaus, A. (2013) Penyimpangan Etika Bisnis Usaha Micro Dalam Perspective Fenomenology Sechler dan Weber (Study Kualitatif pada Prouk Tahu dan Ayam Potong Oleh Usaha Mikro di Pasar Hrapanjaya, Kota Bekasi, Provinsi Jawa Barat, Indonesia). Journal Applikasi Manajemen, 11, 21-33.

[23] Burkholder, D.U. (2009) Returning Counselor Education Doctoral Students: Issues of Retention and Perceived Experiences. College and Graduate School of Education Kent State University, Kent.

[24] Russo-Netzer, P. (2014) Spiritual Identity outside Institutional Religion: A Phenomenological Exploration. An International Journal of Theory and Research, 14, 19-42. https://doi.org/10.1080/15283488.2013.858224

[25] Hsieh, H.-F. and Shannon, S.E. (2005) Three Approaches to Qualitative Content Analysis. Qualitative Health Research, 15, 1277-1288. https://doi.org/10.1177/1049732305276687

[26] Creswell, J.W. (2003) Research Design: Qualitative, Quantitative, and Mixed Method Approaches. Sage Publication Inc., Thousand Oak. 